\title{
MULTIVARIATE ANALYSIS OF VARIATION WITHIN THE INSULARIA COMPLEX OF THE MOTH BISTON BETULARIA
}

\author{
R. C. STEWARD \\ Department of Zoology, University College, Cardiff
}

Received 22.x.76

\begin{abstract}
SUMmary
A multivariate analysis of the colour variation of the moth Biston betularia has been carried out. Previous workers have demonstrated that the black form, carbonaria, and the intermediate form, insularia, are controlled by alleles at the same locus. The results of the present analysis of the variation of the insularia phenotype in different populations and in 20 families show that there are at least three distinct insularia morphs and suggest that these are controlled by three different insularia alleles. There is evidence that the allele, which in the heterozygous state produces the palest insularia form, is incompletely dominant. For this reason an objective means of classification, considering several different variables, is required to distinguish the three insularia forms. The scoring method that was devised was used to classify insularia in samples from south Wales. In this area the darkest insularia morph reaches its highest frequencies in urban areas.
\end{abstract}

\section{INTRODUCTION}

THE colour morphs of the moth Biston betularia (L.) can be divided into three main categories: the black form, carbonaria (=doubledayaria); the intermediate form, insularia and the pale typical form. Several workers (e.g. Bowater, 1914) have shown that carbonaria is inherited as a single gene, dominant in expression to typical. Doncaster (1906) considered that the term insularia included several distinct forms and Kettlewell (1973) scores insularia into five categories. Clarke and Sheppard (1964) demonstrated that an insularia form was controlled by an allele at the same locus as carbonaria and that carbonaria was dominant to insularia, which in turn was dominant to typical. Lees (1968) showed that this was also the case for a darker insularia form.

These results suggest that the insularia complex may in fact include a range of phenotypes produced by several alleles. Evidence supporting this is found in the work of Bowater (1914), who in one family (11.20) seems to have obtained a clear segregation of a dark insularia and a paler insularia form. In addition, Lemche (1931) seems to have demonstrated allelism of two distinct insularia forms. However, Lemche scored all insects with completely black abdomens as carbonaria and so regarded the dark insularia form in his families as carbonaria, although the photographs given in his paper indicate that these were insularia.

There is general agreement (Kettlewell, 1973; Lees, 1974) that there are several distinct insularia forms but, as these phenotypes tend to intergrade with each other, some objective means of classifying the moths is required to compare the range of variation in different samples and families of moths. In this study a multivariate scoring method was used to examine the distinction between carbonaria, insularia and typical and then to examine the range of variation in the insularia progeny in families of known parentage.

$39 / 1-G$ 


\section{THE SCORING PROCEDURE}

For each moth, 13 areas of the dorsal surface of the wings and body, shown in fig. 1, were examined and scored on an eight-point scale for the

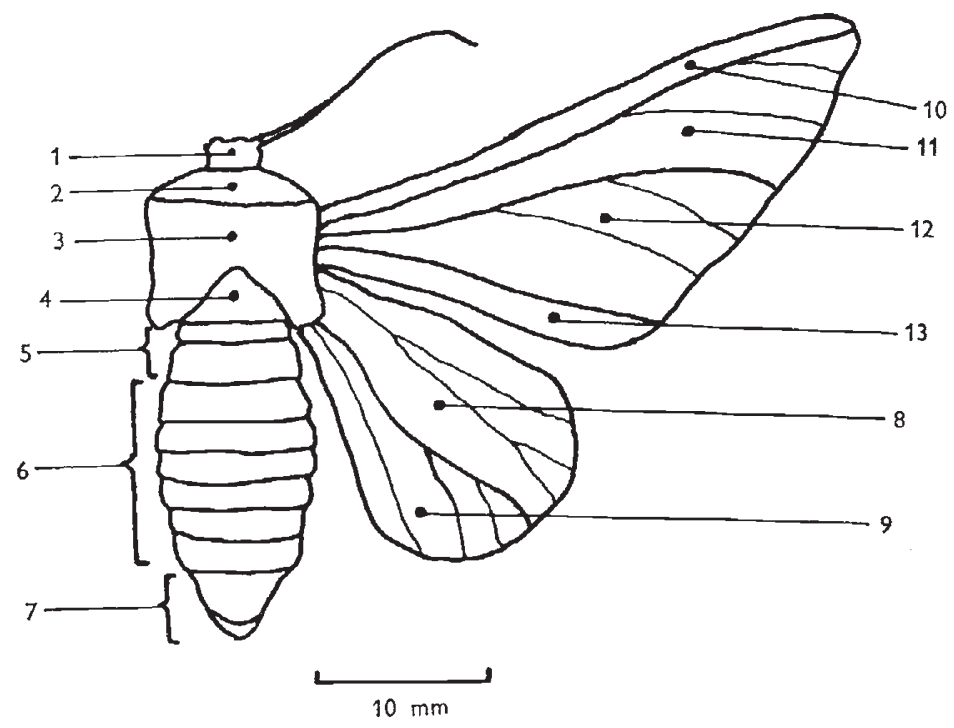

Fic. 1.-Diagram, showing the dorsal view of an imago of $B$. betularia, to indicate the 13 areas distinguished in the multivariate scoring system. The boundaries between the wing areas are the veins shown in thicker lines. Only the veins which are of importance in delineating the areas are represented.

relative amounts of black and white scales present in each area. The condition represented by the different values can be summarised as:

$0=$ No, or very few, black scales.

$1=$ Predominantly white, with small areas of black scales.

$2=$ White and black scales intermingled, approximately equal numbers of each.

3 = Predominantly black but a continuous " network" of white areas.

4 = Black, but with the whole area affected by small areas of white scales.

$5=$ Black, with a fine speckling of white scales over the whole area.

6 = Black, with white speckling affecting less than a third of the area.

$7=$ No white scales.

In the preliminary work the ventral surface of the moths was also scored but this was discontinued as the darkness of a given ventral area was found to be highly correlated with the darkness of the corresponding dorsal area. By scoring individual moths at intervals of several days, it was confirmed that this method of scoring was consistent for the same observer.

\section{The Distinction BetWeen carbonaria, insularia And typlaAL}

The principal components of the 13 variables were calculated, using a computer programme in the University of California BMD series, for 
carbonaria, insularia and typicals in random samples from localities in England and Wales. Plotting the individuals' scores on the first two principal components indicated that carbonaria and typical are clearly distinct from the range of forms labelled insularia. The criteria used for distinguishing these three main categories are discussed below. Only the results for the analysis of the variation within the insularia phenotype are presented in detail in this paper but many other analyses were carried out which confirmed the distinction between carbonaria, insularia and typical.

Previous workers have shown that insularia is inherited as a single gene. Therefore, if an insularia/typical heterozygote is crossed with a typical, then all the insularia progeny must be carrying the same insularia allele and so the range of variation within this family represents the effects of the genetic and external environments on the expression of the insularia allele. In order to investigate the number of distinct phenotypes included within insularia, the ranges of variation in different family groups of insularia were compared.

\section{The families of insularia anAlysed}

The majority of the moths were from 14 families of $B$. betularia reared in this study (table 1). All the insularia progeny (except for crippled moths) and at least half of the carbonaria and typical progeny of these families, were

TABLE 1

Origin of the parents of the families of

B. betularia reared in this study

\begin{tabular}{|c|c|c|}
\hline Family & Male parent & Female parent \\
\hline $\mathrm{B} / 10 / 72 \mathrm{~L}$ & insularia ex Wytham (Oxford) & typical ex stock \\
\hline $\mathrm{B} / 3 / 73$ & typical ex Beddau & insularia ex stock* \\
\hline $\mathrm{B} / 6 / 73$ & typical ex Cardiff & insularia ex $\mathrm{B} / 10 / 72 \mathrm{~L}$ \\
\hline $\mathrm{B} / 7 / 73$ & carbonaria ex Beddau & insularia ex B/10/72L \\
\hline $\mathrm{B} / 8 / 73$ & insularia ex stock* & insularia ex B/10/72L \\
\hline $\mathrm{B} / 13 / 74$ & insularia ex Beddau & typical ex B/6/73 \\
\hline $\mathrm{B} / 14 / 74$ & insularia ex Beddau & insularia ex stock* \\
\hline $\mathrm{B} / 16 / 74$ & insularia ex Beddau & insularia ex stock* \\
\hline $\mathrm{B} / 18 / 74$ & insularia ex $\mathrm{B} / 7 / 73$ & typical ex $\mathrm{B} / 6 / 73$ \\
\hline $\mathrm{B} / 19 / 74$ & insularia ex $\mathrm{B} / 7 / 73$ & typical ex $\mathrm{B} / 6 / 73$ \\
\hline $\mathrm{B} / 21 / 74$ & carbonaria ex B/7/73 & insularia ex $\mathrm{B} / 7 / 73$ \\
\hline $\mathrm{B} / 23 / 74$ & insularia ex $\mathrm{B} / 3 / 73$ & typical ex B/2/73 \\
\hline $\mathrm{B} / 26 / 74$ & insularia ex $\mathrm{B} / 6 / 73$ & insularia ex $\mathrm{B} / 6 / 73$ \\
\hline $\mathrm{B} / 29 / 74$ & (light) carbonaria ex $\mathrm{B} / 4 / 73$ & insularia ex $\mathrm{B} / 3 / 73$ \\
\hline
\end{tabular}

* Indicates that the parent originated from a family reared by Dr D. R. Lees, involving a cross between a typical and a melanic parent, so that any melanic offspring are known to be heterozygous. In Dr Lees' crosses a melanic male captured at Beddau was mated with a female from laboratory stock (ex Oxford).

scored for all 13 variables on the day of emergence. The families were all reared under the same conditions except that, whereas most families were fed on sallow (Salix spp.) foliage collected at Cardiff, some families were fed on sallow foliage collected at a locality where air pollution levels are higher. There was no evidence that this difference in larval treatment had any effect on the colour of the adult progeny. Of the 14 families, the moths of $\mathrm{B} / 10 / 72 \mathrm{~L}$ were part of a large family resulting from a cross set up by Dr D. R. Lees. To avoid confusion in referring to families, those crosses set up by $\mathrm{Dr}$ Lees are marked "L". 
A random selection of the insularia from five families $(\mathrm{B} / 1 / 67 \mathrm{~L}, \mathrm{~B} / 5 / 67 \mathrm{~L}$, $\mathrm{B} / 8 / 72 \mathrm{~L}, \mathrm{~B} / 9 / 72 \mathrm{~L}$ and $\mathrm{B} / 8 / 73 \mathrm{~L}$ ), reared by $\mathrm{Dr} \mathrm{D}$. R. Lees, were also scored. The details of the parentage of $\mathrm{B} / \mathrm{l}$ and $\mathrm{B} / 5 / 67 \mathrm{~L}$ are given in Lees (1968). $\mathrm{B} / 8 / 72 \mathrm{~L}, \mathrm{~B} / 9 / 72 \mathrm{~L}$ and $\mathrm{B} / 8 / 73 \mathrm{~L}$ resulted from crosses between male insularia from south Wales samples and typical females from stock. The other insularia were from a family $(\mathrm{B} / \mathrm{MT} / 25)$ reared at Merthyr Tydfil. This consists of 50 insularia and 47 typicals with about equal numbers of males and females and is laid out in a separate storage case in the "Fleming Duplicate" Lepidoptera Collection in the Welsh National Museum at Cardiff. All the moths of this family emerged within a 3-week period in May 1925. No parents for this family could be found but the segregation indicates that the progeny resulted from a cross between an insularia/typical heterozygote and a typical.

\section{ANAlysis Of VARIATION IN FAMILY Groups of insularia}

(i) Principal component analysis

The principal components of the 13 variables were calculated for insularia from eight families. The scores of the individuals on the first two components are shown in fig. 2. In six of the families $(\mathrm{B} / 1, \mathrm{~B} / 3, \mathrm{~B} / 5, \mathrm{~B} / 6$, $\mathrm{B} / 7, \mathrm{~B} / \mathrm{MT}$ ) all of the insularia progeny within a given family must have been carrying the same insularia allele. The insularia progeny within any one of these families have similar scores on the two components. The insularia from $\mathrm{B} / 6 / 73$ and $\mathrm{B} / 7 / 73$, which were pale forms of insularia, show a similar range of scores on the two components and have large positive scores on component 1 , while the dark insularia from $\mathrm{B} / 3 / 73$ have large negative scores on component 1 . The insularia from B/1/67L, B/5/67L and B/MT/25 tend to cluster together and have intermediate scores on component $\mathrm{l}$ and, although their scores on this component overlap to a certain extent with insularia from $\mathrm{B} / 3, \mathrm{~B} / 6$ and $\mathrm{B} / 7$, if the scores on component 2 are also taken into account there is good separation of the "clusters" of insularia families.

The clustering of family groups of insularia suggests that there are three distinct insularia alleles involved, each producing a different range in variation. Further evidence of this comes from the scores of the insularia progeny of $\mathrm{B} / 8 / 72 \mathrm{~L}$ and $\mathrm{B} / 9 / 72 \mathrm{~L}$. The male parents for these two crosses were homozygous for insularia, although both individuals may have been carrying two different insularia alleles. It is likely, therefore, that in both families two different insularia alleles were segregating. For each family, fig. 2 shows that the progeny are partitioned between the two groups at either end of componcnt 1 ; none occurs in the "intermediate" group.

The results of the analyses summarised in fig. 2 and many similar analyses suggest that insularia within a given family, in which only one allele can be segregating, show only a limited range in variation, compared with that of the whole insularia complex, and that families involving the same insularia phenotype show a similar range in variation. From these analyses, it seems that the pale phenotypes in $\mathrm{B} / 8 / 72 \mathrm{~L}, \mathrm{~B} / 9 / 72 \mathrm{~L}$ and the insularia progeny of $B / 6 / 73$ and $B / 7 / 73$ are all representatives of the range in one phenotype, designated $\mathrm{P}$ insularia, while the dark phenotypes of $\mathrm{B} / 8 / 72 \mathrm{~L}$ and $\mathrm{B} / 9 / 72 \mathrm{~L}$ and the insularia progeny of $\mathrm{B} / 3 / 73$ represent the range in expression of the darkest insularia phenotype, here labelled $\mathrm{D}$ insularia. A 


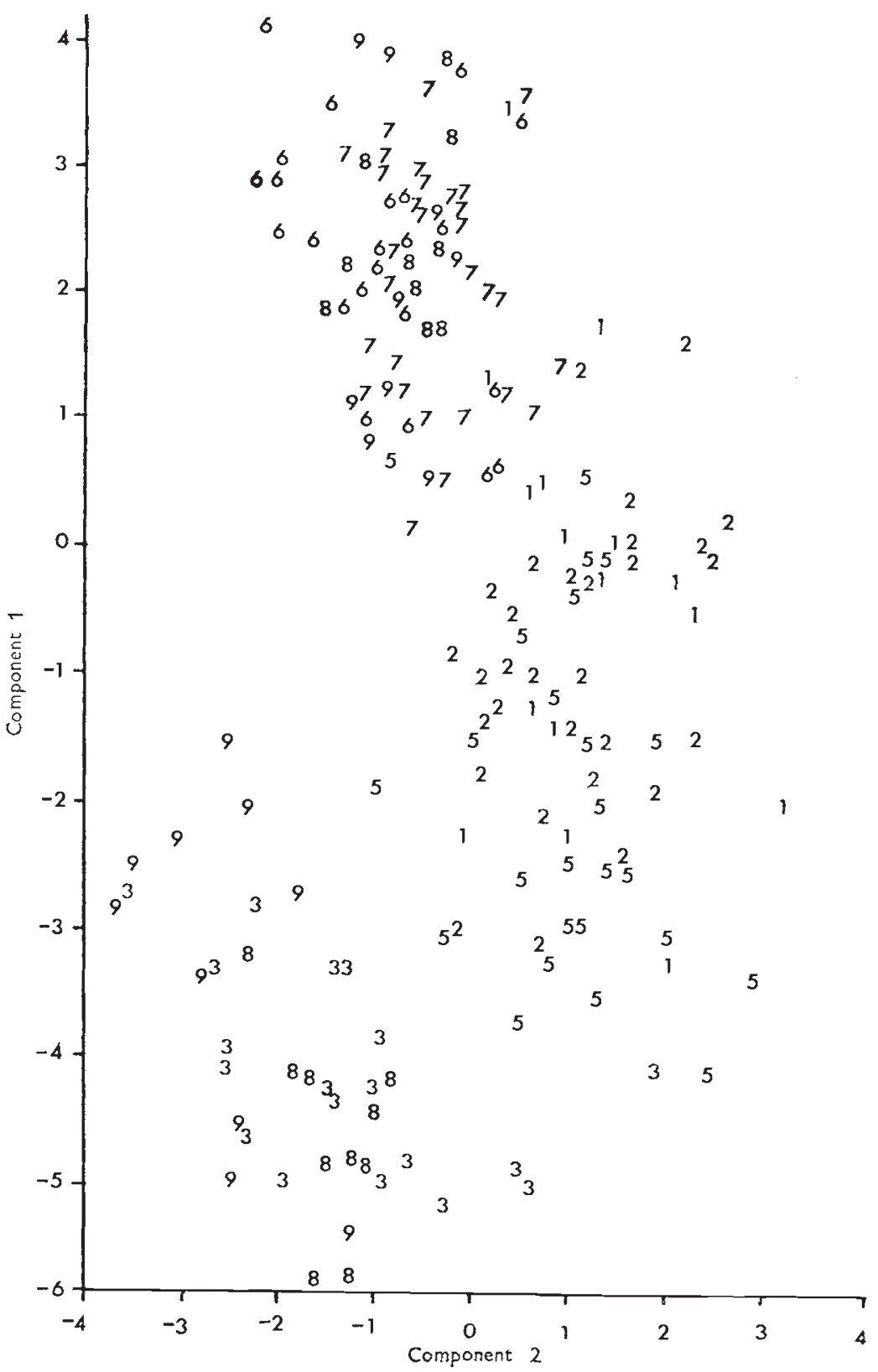

Frg. 2.-Principal component analysis of the insularia progeny of several families. A plot of the individuals' scores on the first two principal components is shown. On component 1, paler insularia have large positive scores and dark insularia have large negative scores. To distinguish the families: $1=\mathrm{B} / 1 / 67 \mathrm{~L}, 2=\mathrm{B} / \mathrm{MT} / 25,3=\mathrm{B} / 3 / 73,5=\mathrm{B} / 5 / 67 \mathrm{~L}$, $6=\mathrm{B} / 6 / 73,7=\mathrm{B} / 7 / 73,8=\mathrm{B} / 8 / 72 \mathrm{~L}, 9=\mathrm{B} / 9 / 72 \mathrm{~L}$. 
third phenotypc, labclled $M$ insularia, seems to be present in $\mathrm{B} / \mathrm{MT} / 25$, $\mathrm{B} / 1 / 67 \mathrm{~L}$ and $\mathrm{B} / 5 / 67 \mathrm{~L}$.

To examine whether a similar grouping of the phenotypes would result from a different form of analysis, a random selection of the insularia from the families was classified into three groups using the "Classify" Computer programme in the Genstat series. This programme finds an optimum grouping for a given number of categories. No assumptions about the relationship of the individuals are made at the start of the analysis. During the analysis, individuals are moved between groups so that the variance within each group is minimised. Table 2 indicates that the three groups formed in the analysis correspond to $\mathrm{P}$ insularia, $\mathrm{M}$ insularia and $\mathrm{D}$ insularia.

TABLE 2

Results of using Genstat classify program for classification into three groups

Number of

$\begin{array}{lcccc}\begin{array}{l}\text { Family } \\ \text { (Pinsul) }\end{array} & \text { cases } & \text { Group 1 } & \text { Group 2 } & \text { Group 3 } \\ \text { B/8/72L } & & & & \\ \text { B/9/72L } & 10 & 10 & 0 & 0 \\ \text { B/6/73 } & 21 & 20 & 1 & 0 \\ \text { B/7/73 } & 24 & 23 & 1 & 0 \\ \text { (Minsul) } & 30 & 30 & 0 & 0 \\ \text { B/MT/25 } & & & & \\ \text { B/1/67L) } & 30 & 2 & 28 & 0 \\ \text { B/5/67L } & 17 & 5 & 12 & 0 \\ \text { (Pinsul }+ \text { Minsul) } & 25 & 1 & 22 & 2 \\ \text { B/8/73L } & 52 & 38 & 14 & 0 \\ \text { (Dinsul) } & & & & \\ \text { B/8/72L } & 12 & 0 & 0 & 12 \\ \text { B/9/72L } & 10 & 0 & 0 & 10 \\ \text { B/3/73 } & 21 & 1 & 2 & 18\end{array}$

(ii) Discriminant function analysis

Representatives of $\mathrm{P}$ insularia from $\mathrm{B} / 8 / 72 \mathrm{~L}, \mathrm{~B} / 9 / 72 \mathrm{~L}$ and $\mathrm{B} / 7 / 73$, of $\mathrm{M}$ insularia from $\mathrm{B} / \mathrm{MT} / 25$, and of $\mathrm{D}$ insularia from $\mathrm{B} / 8 / 72 \mathrm{~L}, \mathrm{~B} / 9 / 72 \mathrm{~L}$ and $\mathrm{B} / 3 / 73$ were used to calculate discriminant functions for the three insularia phenotypes, using the University of California Computer programme, BMD 07M. The discriminant functions (linear functions of the 13 original variables) that were calculatcd were used to classify the insularia progeny and insularia parents of the farnilies (table 3).

For the 12 families in which only one insularia allele can have been segregating (Group 1, table 3), all the insularia progeny of a given family tend to be classified into one of the three categories and the scoring of the insularia progeny agrees with that of the insularia parent (where available). These results suggest that the variation in the insularia complex is determined by three different insularia alleles, each of which has a limited range in variation, which only overlaps to a small extent with the "neighbouring" phenotypes. On this basis only 75 out of the 598 insularia progeny of the 12 families are mis-classified in table 3 . The suggestion that the dark insularia and pale insularia segregating in $\mathrm{B} / 8 / 72 \mathrm{~L}$ and $\mathrm{B} / 9 / 72 \mathrm{~L}$ are controlled by two allelomorphs inherited at the carbonaria locus has been confirmed by rearing investigations carried out by Dr D. R. Lees (Lees and Creed, 1977). 
TABLE 3

Results of using discriminant analyses to classify insularia families into three phenotypes

\begin{tabular}{llllllr}
\multicolumn{1}{c}{$\begin{array}{c}\text { Classification of } \\
\text { Parents }\end{array}$} & \multicolumn{3}{c}{$\begin{array}{c}\text { Classification of insularia } \\
\text { Progeny }\end{array}$} \\
Family & $\overbrace{\text { Male }}$ & Female & & Pinsul & Minsul & Dinsul \\
1. Families in which only one insularia & allele should be segregating \\
B/MT/25 & ? & ? & 0 & 48 & 0 \\
B/1/67L & Typical & carbonaria & 4 & 13 & 0 \\
B/5/67L & Typical & carbonaria & 1 & 20 & 4 \\
B/3/73 & Typical & Dinsul & 0 & 8 & 40 \\
B/6/73 & Typical & Pinsul & 52 & 3 & 0 \\
B/7/73 & carbonaria & Pinsul & 68 & 1 & 0 \\
B/13/74 & Pinsul & Typical & 62 & 3 & 0 \\
B/18/74 & Pinsul & Typical & 69 & 9 & 0 \\
B/19/74 & Pinsul & Typical & 34 & 11 & 0 \\
B/21/74 & carbonaria & Pinsul & 55 & 14 & 0 \\
B/23/74 & Dinsul & Typical & 1 & 14 & 47 \\
B/29/74 & carbonaria & Dinsul & 1 & 1 & 13
\end{tabular}

2. Families in which both parents were heterozygous insularia

$\begin{array}{lllrrr}\text { B/8/73L } & \text { Pinsul } & \text { Pinsul } & 60 & 31 & 0 \\ \text { B/14/74 } & \text { Minsul } & \text { Pinsul } & 53 & 62 & 0 \\ \text { B/16/74 } & \text { Pinsul } & \text { Pinsul } & 56 & 24 & 0 \\ \text { B/26/74 } & \text { Pinsul } & \text { Pinsul } & 114 & 8 & 0 \\ \text { B/8/73 } & \text { Dinsul } & \text { Minsul } & 18 & 7 & 37\end{array}$

3. Families in which " homozvgous" insularia was crossed with typical

$\begin{array}{lllllr}\text { B/8/72L } & \text { Dinsul } & \text { Typical } & 10 & 0 & 12 \\ \text { B/9/72L } & \text { Dinsul } & \text { Typical } & 20 & 1 & 10 \\ \text { B/10/72L } & \text { Minsul } & \text { Typical } & 53 & 7 & 0\end{array}$

\section{ORdER OF DOMINANCE OF THE insularia PHENOTYPES}

The segregations in the crosses between "homozygous" insularia and typical (Group 3, table 3) can be explained if the male parents of B/8/72L and $\mathrm{B} / 9 / 72 \mathrm{~L}$ carried both the $\mathrm{P}$ insularia and $\mathrm{D}$ insularia alleles, while the male parent of $\mathrm{B} / 10 / 72 \mathrm{~L}$ was homozygous for $\mathrm{P}$ insularia. The progeny in $\mathrm{B} / 10 / 72 \mathrm{~L}$ were therefore all genotypically $\mathrm{P}$ insularia/typical heterozygotes and this is consistent with the scoring of families in which an insularia from $\mathrm{B} / 10 / 72 \mathrm{~L}$ was used as one of the parents (table 1). However, the scoring of the parent of $\mathrm{B} / 10 / 72 \mathrm{~L}$ as $\mathrm{M}$ insularia suggests that homozygous $\mathrm{P}$ insularia may be darker than the $\mathrm{P}$ insularia/typical heterozygotes. Cadbury (Kettlewell, 1973) has suggested that homozygous insularia may be darker than heterozygotes. In discussion of the appearance of the "insularia heterozygotes" in this paper it is the insularia/typical heterozygote which is being referred to, while those insularia which were not carrying either a carbonaria or a typical allele are referred to as "insularia homozygotes".

In this paper the three insularia alleles which are considered to be involved are distinguished according to the phenotype which they produce in the heterozygous state with typical. None of the families examined involved homozygotes of the $\mathrm{M}$ insularia and $\mathrm{D}$ insularia alleles.

The phenotypes of the male parents of $\mathrm{B} / 8 / 72 \mathrm{~L}$ and $\mathrm{B} / 9 / 72 \mathrm{~L}$ indicate that the $\mathrm{D}$ insularia allele is dominant in expression to the $\mathrm{P}$ insularia allele. 
This is also indicated by the segregation in $\mathrm{B} / 8 / 73$ of approximately twice as many $\mathrm{D}$ insularia as $\mathrm{P}$ insularia phenotypes. The female parent of $\mathrm{B} / 8 / 73$ originated from $\mathrm{B} / 10 / 72 \mathrm{~L}$ and so must have been genotypically a $\mathrm{P}$ insularia/ typical heterozygote, although it was one of the darkest of the progeny of $\mathrm{B} / 10 / 72 \mathrm{~L}$.

Kettlewell (1973) has suggested that the order of dominance among the insularia phenotypes is likely to be in order of increasing darkness. This is supported by the results of a cross between a $\mathrm{M}$ insularia and a $\mathrm{P}$ insularia $(\mathrm{B} / 14 / 74)$. If $\mathrm{M}$ insularia were dominant to $\mathrm{P}$ insularia, then among the insularia progeny of $\mathrm{B} / 14$ there should be a ratio of $2 \mathrm{M}$ insularia : $1 \mathrm{P}$ insularia. Table 3 shows that there is some indication of this ratio, with more $\mathrm{M}$ insularia than $\mathrm{P}$ insularia among the progeny of this family. In both $\mathrm{B} / 8 / 73$ and $\mathrm{B} / 14 / 74$ the overall segregation ratio of insularia : typical was not significantly different $(P>0 \cdot 05)$ from the expected $3: 1$ ratio.

It is possible to examine the suggestion that "homozygous $\mathrm{P}$ insularia" may be phenotypically $\mathrm{M}$ insularia by considering three families which were crosses between two $\mathrm{P}$ insularia/typical heterozygotes, namely $\mathrm{B} / 8 / 73 \mathrm{~L}$, $\mathrm{B} / 16 / 74$ and $\mathrm{B} / 26 / 74$. In these families, assuming that there is no differential viability of the genotypes, one-third of the insularia offspring should be genotypically homozygous $\mathrm{P}$ insularia and two-thirds should be $\mathrm{P}$ insularial typical heterozygotes. Therefore, from the suggestion that the $\mathrm{P}$ insularia phenotype is the result of incomplete dominance of an allele, which in the homozygous state produces $M$ insularia phenotypes, the insularia progeny of these three families would be expected to show a ratio of $2 \mathrm{P}$ insularia : $1 \mathrm{M}$ insularia. For $\mathrm{B} / 16$ and $\mathrm{B} / 26$, only 9 and 11 respectively, of the insularia offspring were too damaged to be scored for all 13 variables. All the other insularia offspring were scored on emergence. For $\mathrm{B} / 8 / 73 \mathrm{~L}$, a random sample $(n=91)$ of the insularia progeny was scored. In $\mathrm{B} / 16 / 74$ and $\mathrm{B} / 8 / 73 \mathrm{~L}$, the overall segregations of insularia to typical were $89 \mathrm{I}: 17 \mathrm{~T}$ and $315 \mathrm{I}: 97 \mathrm{~T}$ respectively. For both families, approximately one-third of the insularia offspring were classified as $\mathrm{M}$ insularia $(\mathrm{B} / 16,24$ out of $80 ; \mathrm{B} / 8,31$ out of 91$)$ while the rest were classified as $\mathrm{P}$ insularia.

In contrast, for $\mathrm{B} / 26$, only eight out of the 122 insularia which were scored, were classified as $\mathrm{M}$ insularia; all the other progeny were scored as $\mathrm{P}$ insularia (Group 2, table 3). The overall ratio of insularia : typical in this family was $133 \mathrm{I}: 69 \mathrm{~T}$, which is significantly different from the expected $3: 1$ ratio $\left(\chi_{1}^{2}=8.56,0.01>P>0.001\right)$ but almost exactly a $2: 1$ ratio. This, even in the absence of any additional information, would strongly suggest that few homozygous insularia had survived to emerge in this family. This provides an explanation of why nearly all of the offspring were phenotypically $\mathrm{P}$ insularia. The segregation in B/26, therefore, both supports the suggestion of incomplete dominance of the $\mathrm{P}$ insularia allele and gives direct evidence of a low fitness of the insularia homozygotes. There is some reason to expect a deficiency of insularia homozygotes in B/26 as it was the only one of the insularia $\times$ insularia families which was fed on polluted foliage. However, as B/26 was not partitioned into two batches, one fed on polluted foliage and the other fed on Cardiff foliage, it is not certain that the apparent deficiency of homozygous insularia was due to the experimental treatment. 'Two other families, involving crosses between insularia/typical heterozygotes and typicals, were partitioned into "experimental " and "control " halves and the results showed that the different diets had not produced any 
difference in the range of darkness of either the insularia or typical phenotypes in these families (unpublished).

The analysis of the variation of the insularia phenotypes within families indicates the existence of three distinct insularia alleles which in the heterozygous state (with typical) produce three different phenotypes. The evidence from families such as $\mathrm{B} / \mathrm{MT} / 25, \mathrm{~B} / 1 / 67 \mathrm{~L}$ and $\mathrm{B} / 5 / 67 \mathrm{~L}$, where heterozygous insularia show a range of variation limited to the $\mathrm{M}$ insularia phenotype, demonstrates that two different alleles are likely to be involved in producing the $\mathrm{M}$ insularia phenotype; one of these alleles is incompletely dominant and in the heterozygous state produces the $\mathrm{P}$ insularia phenotype.

\section{Classification of the insularia in RANDom SAMples}

The conclusion about the number of distinct insularia phenotypes involved comes from a relatively small number of families. However, similar analyses of the insularia in random samples from over 30 localities in England and Wales also indicate that three distinct phenotypes are involved. Table 4 shows the result of using the discriminant functions that were

TABLE 4

Classification of the insularia in random samples into dark, medium and pale phenotypes

\begin{tabular}{|c|c|c|c|c|c|c|c|c|c|}
\hline \multirow[b]{2}{*}{ Locality } & \multirow[b]{2}{*}{ Year } & \multicolumn{3}{|c|}{ Phenotype numbers } & \multicolumn{3}{|c|}{ Phenotype per cent } & \multirow[b]{2}{*}{ Sample } & \multirow{2}{*}{$\begin{array}{l}\text { Summe } \\
\text { smoke }\end{array}$} \\
\hline & & Pinsul & Minsul & Dinsul & Pinsul & Minsul & Dinsul & & \\
\hline Clyne & 1974 & 5 & 1 & 0 & $13 \cdot 1$ & $2 \cdot 6$ & 0 & 38 & 12 \\
\hline Swansea & $1973-4$ & 6 & 2 & 11 & $10 \cdot 9$ & $3 \cdot 6$ & $20 \cdot 0$ & 55 & 23 \\
\hline Tonna & 1973 & 3 & 1 & 7 & $9 \cdot 7$ & $3 \cdot 2$ & $22 \cdot 6$ & 31 & 12 \\
\hline Neath & 1974 & 24 & 9 & 43 & $15 \cdot 0$ & $5 \cdot 6$ & $26 \cdot 9$ & 160 & 21 \\
\hline Margam & 1974 & 11 & 9 & 15 & $13 \cdot 6$ & $11 \cdot 1$ & $18 \cdot 5$ & 81 & 18 \\
\hline Tythegston & 1974 & 10 & 4 & 7 & $19 \cdot 2$ & $7 \cdot 7$ & $13 \cdot 5$ & 52 & 6 \\
\hline Ogmore & 1974 & 21 & 10 & 15 & $15 \cdot 2$ & $7 \cdot 2$ & $10 \cdot 9$ & 138 & 7 \\
\hline Ystradowen & 1973 & 29 & 14 & 11 & $23 \cdot 4$ & $11 \cdot 3$ & $8 \cdot 9$ & 124 & - \\
\hline Ystradowen & 1974 & 40 & 24 & 35 & $14 \cdot 6$ & $8 \cdot 7$ & $12 \cdot 7$ & 275 & - \\
\hline Ystradowen & $1973-4$ & 69 & 38 & 46 & $17 \cdot 3$ & $9 \cdot 5$ & $11 \cdot 5$ & 399 & 9 \\
\hline Radyr & 1973 & 9 & 4 & 8 & $17 \cdot 3$ & $7 \cdot 7$ & $15 \cdot 4$ & 52 & 12 \\
\hline Cardiff & 1973 & 9 & 4 & 7 & $26 \cdot 5$ & $11 \cdot 8$ & $20 \cdot 6$ & 34 & 26 \\
\hline Thornhill & 1973 & 6 & 2 & 5 & $25 \cdot 0$ & $8 \cdot 3$ & $20 \cdot 8$ & 24 & 12 \\
\hline Tongwynlais & 1973 & 11 & 10 & 15 & $13 \cdot 4$ & $12 \cdot 2$ & $18 \cdot 3$ & 82 & 26 \\
\hline Beddau & $1972-3$ & 64 & 28 & 56 & $21 \cdot 6$ & $9 \cdot 5$ & $19 \cdot 0$ & 296 & 13 \\
\hline Cefn Pennar & $1973-4$ & 11 & 1 & 8 & $31 \cdot 4$ & $2 \cdot 9$ & $22 \cdot 9$ & 35 & 40 \\
\hline Abercanaid & 1974 & 15 & 11 & 11 & $16 \cdot 5$ & $12 \cdot 1$ & $12 \cdot 1$ & 91 & 14 \\
\hline Clydach & 1974 & 10 & 5 & 15 & $18 \cdot 2$ & $9 \cdot 1$ & $27 \cdot 3$ & 55 & 17 \\
\hline Bwlch & 1972 & 3 & 4 & 3 & $4 \cdot 5$ & $6 \cdot 0$ & $4 \cdot 5$ & 67 & 12 \\
\hline Sennybridge & 1972 & 0 & 3 & 2 & 0 & $6 \cdot 0$ & $4 \cdot 0$ & 50 & 3 \\
\hline Risca & 1974 & 12 & 7 & 10 & $17 \cdot 9$ & $10 \cdot 4$ & $14 \cdot 9$ & 67 & 21 \\
\hline Llanbeder & 1973 & 6 & 3 & 11 & $11 \cdot 8$ & $5 \cdot 9$ & $21 \cdot 6$ & 51 & 17 \\
\hline Glascoed & 1973 & 21 & 15 & 20 & $18 \cdot 1$ & $12 \cdot 9$ & $17 \cdot 2$ & 116 & 16 \\
\hline Staunton & 1974 & 34 & 14 & 18 & $17 \cdot 3$ & $7 \cdot 1$ & $9 \cdot 2$ & 196 & 9 \\
\hline Much Birch & 1974 & 8 & 4 & 4 & $19 \cdot 5$ & $9 \cdot 8$ & $9 \cdot 8$ & 41 & 9 \\
\hline Marlborough & 1974 & 19 & 1 & 3 & - & - & $\ldots$ & $\cdots$ & - \\
\hline Wytham & 1974 & 23 & 4 & 2 & $\ldots$ & $\ldots$ & - & -- & - \\
\hline
\end{tabular}

The samples from Bwlch, Sennybridge, Marlborough and Wytham were collected by Dr D. R. Lees, and the sample from Beddau was collected by Dr E. R. Creed. The figures for summer smoke concentrations $\left(\mu \mathrm{g} / \mathrm{m}^{3}\right)$ at the sites in south Wales are shown. 
calculated from the insularia families, to classify all of the insularia in 23 random samples from south Wales. In comparison, the classification of insularia in samples from Marlborough and Wytham in southern England is shown.

All threc phenotypes are present in the majority of the samples, although the $\mathrm{M}$ insularia morph is usually the least common phenotype and shows a smaller range in frequency. The total insularia frequency at some sites reaches almost 60 per cent, but the frequencies of the individual insularia morphs never exceed 32 per cent. The carbonaria frequencies in the samples from Margam and Tongwynlais were 17.3 per cent and 18.3 per cent and in all the other samples from south Wales the carbonaria frequency was less than 14 per cent. This means that the phenotype frequencies of the insularia morphs will give a good indication of their actual frequency, although because of the order of dominance, the dark insularia phenotype will tend to obscure the frequencies of the paler insularia forms. Lees and Creed (1977) have found evidence that individuals homozygous for the dark insularia allele may be as dark as carbonaria but the low frequency of the D insularia morph (table 4) indicates that this genotype will be rare.

\section{Discussion}

Analysis of the phenotypic variation of $B$. betularia, in families and over 30 samples, confirms the view that the morphs can be readily allocated to one of three main categories: carbonaria, insularia and typical. Twenty of the families contained insularia progeny and analyses of these families show that at least three distinct morphs are included within insularia.

The analyses, in which carbonaria, insularia and typical were included, confirmed that the qualitative criteria used to distinguish these morphs resulted in a natural distinction between the morphs. The distinction between carbonaria and dark insularia follows that made by Kettlewell (1973). In carbonaria, the fore-wings are either completely black or if white scales are present these are arranged to form a thin broken band across the fore-wing, near the outer margin. Dark and light carbonaria occurred together in samples and in all the families of carbonaria examined; male moths tended to show the white scaling more often than females. The normal range in variation of the carbonaria phenotype is well illustrated in Kettlewell (1973, plate 7.1); the left-hand column shows examples of "dark" carbonaria, while the right-hand column, labelled " ancient heterozygotes ", shows the range of variation in light carbonaria. Examination of samples from southern England and Wales (including London and Birmingham) indicates that the light carbonaria phenotype is widespread.

In contrast to carbonaria, dark insularia always have some white scales on the fore-wing and these are never grouped to form a transverse band. As in carbonaria, females tend to be darker and in extreme examples there are fewer white scales present on the fore-wings than there are on some light carbonaria. Another important characteristic is, that while the dorsal surface of the thorax and abdomen of carbonaria is almost always completely black, dark insularia usually have a small white spot on areas 2 and 5 (fig. 1).

The criteria used to distinguish between the palest insularia forms and typical differ somewhat from those of Kettlewell (1973) but are supported 
by the results of the analyses. A " natural " distinction between insularia and typical seems to result if the term insularia is restricted to those individuals in which the abdomens are black with variable amounts of white patterning and in which the fore-wings have at least as many black as white scales. There is considerable variation in the darkness of the individuals which are consequently classified as typical but only rarely do these forms have both dark wings and dark abdomens. In the typical phenotype, darkening of the fore-wings is due to a spreading of the normal black patterning. This gives the "dark typical" individuals a characteristic blotched appearance, very different from that of the palest insularia forms, in which black and white scales are much more uniformly distributed, so that the fore-wings have a pale greyish appearance.

It is likely that there may be several distinct forms included within the typical category and Kettlewell (1973, plate 9.1) distinguishes darker forms as " insularia 1" and " insularia 2". However, close examination of the typical progeny in families suggested that, although the typical offspring within different families showed different ranges of variation in the darkness of the wings and body, there was no evidence of segregation into distinct phenotypes among the typical offspring within a single family. If subsequent rearing investigations showed that there was a dark phenotype within the typical category, which was inherited as a multiple allelomorph of carbonaria, this form could be regarded as a fourth insularia phenotype. The present evidence, however, suggests that the different typical phenotypes may be under polygenic control and affected by environmental influences. The variation in the typical phenotype is likely to be of considerable interest and recording the variation in the typical phenotype in different samples, by distinguishing between the paler and darker "typical " morphs, may prove to be of great value.

In contrast to the evidence that qualitative characters give an efficient separation of carbonaria, insularia and typical, the examination of the variation within insularia suggests that a more quantitative scoring method is required to classify these individuals. This seems to be because of the wide range in the variation of the $\mathrm{P}$ insularia phenotype. The results of canonical analyses, in which the insularia progeny of different families, in each of which only one insularia allele could be segregating, were entered as separate groups, indicated that in different families the $\mathrm{P}$ insularia morph showed the same range in variation and had very similar mean values for the variables. Examination of the range in the insularia phenotype by eye suggests that the variation in the $\mathrm{P}$ insularia morph accounts for more than half of the variation in darkness of insularia. Thus, although the results of classifying insularia " by eye " into three categories agree closely with the phenotypes " insularia 5 , 4 and 3 " distinguished by Kettlewell (1973, plate 9.1), "insularia 3 and 4 " both come within the range of $\mathrm{P}$ insularia. D insularia corresponds with insularia 5 but $M$ insularia would come somewhere between categories 4 and 5. Similarly, of the three forms shown by Lees and Creed (1975) to represent the range in variation of insularia, the two paler forms are $\mathrm{P}$ insularia, while the darkest form would probably be scored as $\mathrm{M}$ insularia. Douwes et al. (1973) use a similar scoring method to that of Kettlewell (1973).

Examination of insularia individuals classified by the computer programme into the three morphs suggests that:

$\mathrm{P}$ insularia are those insularia in which the fore-wing areas 10 and 13 
(fig. 1) have white markings larger than $1 \mathrm{~mm}$ in diameter, while areas 11 and 12 have a continuous network of white scales.

$\mathrm{M}$ insularia are specimens in which areas 10 and 13 are black with a few scattered white spots (less than $1 \mathrm{~mm}$ in diameter) and areas 11 and 12 are predominantly black with numerous white spots which tend, however, to remain distinct and not to merge as in $\mathrm{P}$ insularia. The thorax, abdomen and hind-wings are also darker for $\mathbf{M}$ insularia than for $\mathbf{P}$ insularia.

$\mathrm{D}$ insularia superficially resemble $\mathrm{M}$ insularia in general darkness of the body and wings but, whereas in $M$ insularia the white spotting on the forewings causes the central part of areas 11 and 12 to be markedly paler than the rest of the wing, in D insularia the fore-wings are uniformly dark, with a light and more or less even scattering of white specks, each less than $1 \mathrm{~mm}$ in diameter.

The evidence from this study, together with the results of previous work by Lemche (1931), Clarke and Sheppard (1964) and Lees (1968), suggests that there are at least three distinct insularia morphs, each of which is produced in the heterozygous state by a multiple allelomorph of carbonaria. Lees (1968) has demonstrated that the $\mathrm{M}$ insularia of $\mathrm{B} / 1 / 67 \mathrm{~L}$ and $\mathrm{B} / 5 / 67 \mathrm{~L}$ are allelic to carbonaria, while Clarke and Sheppard (1964) demonstrated this for a paler insularia form (P insularia ?). The evidence obtained by Lees and Creed (1977) of allelism between P insularia, D insularia and carbonaria indicates that all three insularia morphs are inherited as multiple alleles. The segregations of carbonaria, insularia and typical in crosses between $\mathrm{P}$ insularia and carbonaria (B/7, B/21), and between $\mathrm{D}$ insularia and carbonaria $(\mathrm{B} / 29)$, were consistent with this suggestion.

The evidence of incomplete dominance of an insularia allele seems to be of particular importance, as the great majority of melanic forms which have been studied have been found to be controlled by single genes, completely dominant in expression (Lees, 1974). There is the possibility that for an established laboratory stock of insularia it may be possible to distinguish between heterozygotes and homozygotes with a reasonable degree of accuracy, using a multivariate scoring system. This may prove to be of considerable advantage in genetic investigations.

The parents of the families reared in this study originated from Oxford, Cardiff or Beddau ( $16 \mathrm{~km}$ north-west of Cardiff). However, the incomplete dominance of the "P insularia" allele cannot be explained as being simply a result of crossing individuals from different populations, as it was observed in $B / 16 / 74$, in which both parents were of south Wales origin, and in $\mathrm{B} / 10 / 72 \mathrm{~L}$, where both parents originated from Oxford.

If the phenotype frequencies of the insularia morphs in the 23 samples from south Wales are compared with measurements of summer smoke levels $\left(\mu \mathrm{g} / \mathrm{m}^{3}\right)$ at the nearest available recording site (Anon., 1965-73) there is evidence that both the dark and the pale insularia morphs reach their highest frequencies in urban areas. The correlation coefficient of $\mathrm{D}$ insularia frequency with square root summer smoke concentration is $0.615(0.01>\mathrm{P}>$ 0.001 ), while for $\mathrm{P}$ insularia frequency the correlation with square root summer smoke is $0.461(0.05>\mathrm{P}>0.02)$. In contrast the correlation of $\mathrm{M}$ insularia frequency with square root summer smoke is only $-0 \cdot 046$. Estimates of the relative crypsis of the insularia morphs and the carbonaria and typical forms, using a similar method to that of Lees and Creed (1975) indicate that the crypsis of the D insularia morph is greatest in polluted areas, 
while that of $\mathrm{P}$ insularia is greatest in rural areas. Therefore, the variation in $\mathrm{D}$ insularia frequency in south Wales might be partially determined by selective predation but the positive relationship between $\mathrm{P}$ insularia frequency and pollution is the opposite to that which would be expected if selective predation were responsible for the variation in the frequency of this morph.

Acknowledgments. - I am very grateful to Dr E. R. Creed and Dr D. R. Lees for their encouragement and advice during this study and for their many helpful comments on a draft of this paper. The rearing work in this study was greatly facilitated by my being able to use, as parents for some of my families, moths which originated from families reared by Dr Lees. I was also fortunate in being able to examine several samples collected by $\mathrm{Dr}$ Creed, several samples collected by Dr Lees and progeny resulting from five families reared by Dr Lees.

\section{REFERENGES}

ANON. 1965-73. The investigation of air pollution. Warren Spring Laboratory, Annual Summaries.

Bowater, w. 1914. Heredity of melanism in Lepidoptera. 7. Genet., 3, 299-315.

CLARKE, C. A., AND SHEPPARD, P. M. 1964. Genetic control of the melanic form insularia of the moth Biston betularia. Nature, 202, 215-216.

DONCASTER, L. 1906. Collective enquiry as to progressive melanism in Lepidoptera. Entomologist's Rec. F. Var., 18, 207.

Douwes, P., PETERsen, B., AND Vestegren, A. 1973. Melanism hos Biston betularius. I. Danmark och Södra Sverige. Entomologen, 2:1, 15-20.

kettlewell, H. B. D. 1973. The Evolution of Melanism. Clarendon Press, Oxford.

LEES, D. R. 1968. Genetic control of the melanic form insularia of the peppered moth Biston betularia (L.). Nature, Lond., 220, 1249-1250.

LEES, D. R. 1974. The genetic control of the melanic forms of the moth Phigalia pedaria (pilosaria). Heredity, 33, 145-150.

LEES, D. R., AND CREED, E. R. 1975. Industrial melanism in Biston betularia: the role of selective predation. 7. Anim. Ecol., 44, 67-83.

LEES, D. R., AND CREED, E. R. 1977. The genetics of the insularia forms of the Peppered Moth Biston betularia. Heredity, 39, 67-73.

LEMCHe, н. 1931. Amphidasis betularia (L.) and its melanic varieties. F. Genet., 24, 235-241. 